Sven Tarp*

\title{
Den kommercielle leksikografis synder Pia Vater: Spansk-Dansk Ordbog. København: Gyldendal, 2000
}

Gyldendals Spansk-Dansk Ordbog er nu kommet i sin fjerde udgave. Som i den foregående udgave har den kun en forfatter, nemlig Pia Vater, der i øvrigt har været hovedredaktør helt fra første udgave. If $\varnothing$ lge forfatterens forord er fjerde udgave af Spansk-Dansk Ordbog nu på 54.000 opslagsord, dvs. en udvidelse på ca. 3.000 ord. Den nye udgave er »gennemrevideret og samtidig gjort væsentlig mere overskuelig«. Denne angiveligt større overskuelighed er det svært at befinde belæg for. Ved prøveopslag viser de fleste artikler sig således at have nøjagtig den samme struktur og layout som i tredje udgave. Og desuden er ordlisten i den nye udgave ligesom i den foregående opdelt i tre spalter på hver side, hvad der både har fordele og ulemper. På den ene side bliver siden mere uoverskuelig og søgning efter opslagsord, der er placeret i miderste spalte, vanskeligere og langsommeligere. På den anden side bliver den enkelte artikels æstetik væsentligt forbedret, når det som i denne ordbog hovedsagelig drejer sig om korte artikler. Og endelig sparer man sider og undgår en for tung bog, som kan give infiltrationer og andre arbejdsbetingede skader hos den flittige bruger. Men lige netop overskuelighed er det altså så som så med.

Hvad angår den revidering, som også omtales i forordet, er der flere eksempler på dette. For det første følger ordbogen nu - nærmest obligatorisk - det nye spanske alfabet, hvor $c h$ og $l l$ ikke længere regnes som selvstændige bogstaver. For det andet - og ikke mindst - er der mange

Sven Tarp

Spansk Institut

Handelshфjskolen i Århus

Fuglesangs Allé 4

DK-8210 Arhus V

st@asb.dk 
steder sket en klar forbedring med hensyn til omfanget af ordforbindelser og disse præsentation. Et eksempel herpå er artiklen bota:

bota $f$. 1 st $\varnothing$ vle. 2 st $\varnothing$ vlet, ankelst $\varnothing v l e$.

3 læderflaske (til vin). 4 (træ)tønde.

$\square \sim s$ de agua gummistøvler; $\sim s$ de montar ridestøvler; (fig.) T ponerse las

$\sim s$ spinde guld; tjene godt; con las $\sim s$

puestas rejseklar.

Eksempel 1: Artikel fra 3. udgave af Spansk-Dansk Ordbog

bota $f$. 1 st $\varnothing$ vle. 2 st $\varnothing$ vlet, ankelst $\varnothing$ vle.

3 læderflaske (til vin). 4 (træ)tønde.

$\square \sim s$ de agua gummistøvler; $\sim s$ de

montar ridestøvler; (fig.) T ponerse las

$\sim s$ a spinde guld; tjene godt; b tage fra;

gøre sig til gode (con med); estar con

las $\sim$ s puestas være rejseklar; morir

con las $\sim$ s puestas falde på ærens

mark.

Eksempel 2: Artikel fra 4. udgave af Spansk-Dansk Ordbog

Man ser her, hvordan det idiomatiske udtryk ponerse las botas får angivet flere danske oversættelser (forklaringer), ligesom udtrykket con las botas puestas præciseres, så soldater ikke længere dør rejseklare, men falder på ærens mark i erindring om Spaniens muslimske fortid. Sådan er der flere eksempler.

Men der er også bommerter, hvoraf nogle virker helt barokke og fortaber sig i historiens tåger. Slår man for eksempel op under ugedagene (lunes, martes, miércoles, jueves, viernes, sábado, domingo), så er det først under viernes (fredag), at man finder de klassiske og meget anvendte kollokationer, hvori disse ord indgår: el viernes (om fredagen, i fredags, på fredag), el viernes pasado (i fredags), el viernes próximo (på fredag), el viernes por la tarde (fredag eftermiddag), los viernes (om fredagen, hver fredag) osv. Spørgsmålet er nu, hvorfor disse kollokationer kun kan findes under opslagsordet viernes? Og hvordan forlaget forventer, at brugeren skal kunne gætte dette, når man ikke engang orker at bringe henvisninger fra de $\emptyset$ vrige ugedage eller i det mindste forklare dette udsøgte princip i den helt igennem karrige brugervejledning? Kun de få udvalgte, som har sat sig ind i de Røde Ordbøgers lange synderegister, vil overhovedet være klar over, at man engang i tidernes morgen indførte 
det underlige princip at placere alle tilsvarende danske kollokationer under opslagsordet fredag, som er den af de danske ugedage, der kommer først i alfabetet. Ved vending (sic!) af ordbogen er man så åbenbart uforvarende kommet til at placere hele molevitten under den spanske fredag (viernes) og dermed under den ugedag, som kommer sidst i alfabetet. Det er en fejl, som er gået igen siden første udgave.

Men ser man bort fra disse specialiteter, som forlaget nok må tage på sin kappe, kan man konstatere, at Pia Vater har gjort et rimeligt gedigent stykke arbejde i forhold til løfterne i det anæmiske forord og inden for de rammer, som har været udstukket af forlaget. Det virkelige problem er imidlertid disse rammer.

\section{Generelle problemer}

Gyldendals Røde Ordbøger er på flere måder et opblæst foretagende. Man lever på en lang tradition og en tilsyneladende sikker salgssucces, ikke mindst efter fusionen med Munksgaard. Men brugeren - moderne ordbøgers alfa og omega - bekymrer man sig tilsyneladende ikke om. I hvert fald er det på de $\mathrm{i}$ alt 855 sider plus omslag umuligt at finde et eneste tip fra forlaget om, hvad ordbøgerne eventuelt kunne bruges til. Det eneste, man får oplyst, er, at der ud over de Røde Ordbøger i almindelighed findes nogle »store « og nogle »små røde« ordbøger, nogle undervisningsordbøger, der også er »røde«, samt nogle elektroniske ordbøger, som $\varnothing$ jensynlig er farveløse. Nu kan ordbøger imidlertid bruges til mange forskellige ting. Det gælder, uanset om de er mono- eller bilingvale. Alt efter det konkrete formål kræves et bestemt indhold og en tilsvarende opbygning. Men når forlaget i sin arrogance ikke oplyser noget om det konkrete formål, efterlader det ikke alene brugeren, men også anmelderen i en umulig situation. Hvordan skal man bedømme brugbarheden af en ordbog, hvis man ikke ved, hvad den skal bruges til? Der findes faktisk kun én vej til at bedømme kvaliteten af Spansk-Dansk Ordbog: den lange seje vandring over Sukkenes Bro.

Spansk-Dansk Ordbog er som så mange af sine artsfæller en bilingval ordbog. Det fremgår af ordbogens titel og er åbenbart det eneste salgsargument, som forlaget finder nødvendigt. Der findes imidlertid mange måder at opdele ordbøger på. At de er bilingvale, er blot en af disse måder. Men det repræsenterer en meget formel og i bund og grund overfladisk typologi. I gamle dage, da den teoretiske leksikografi endnu var 
i sin vorden, var denne typologi acceptabel, da der stort set ikke fandtes andre inddelingskriterier. Men i dag er den utilstrækkelig og lugter langt væk af et mangelfuldt og gammeldags forlagsarbejde.

En bilingval ordbog er som enhver anden slags ordbog en brugsgenstand, der er - eller bør være - fremstillet for at tilfredsstille bestemte menneskelige behov (se Tarp 1998). For at koncipere en sådan ordbog må man derfor kende - eller definere - brugergruppen og dennes behov. Ingen har i sig selv brug for en »bilingval« ordbog. Det, som brugeren har brug for, er derimod et leksikografisk opslagsværk, som kan hjælpe vedkommende med at skrive, tale, læse, forstå, oversætte og studere et givet sprog osv. Eller for at være mere præcis og videnskabelig, så kan en bilingval spansk-dansk ordbog, der er beregnet på danske brugere, dække over følgende fire hovedfunktioner:

1. reception af mundtlige og skriftlige spanske tekster

2. oversættelse af spanske tekster til dansk

3. produktion af mundtlige og skriftlige spanske tekster

4. tilegnelse af det spanske sprog

Hvis Spansk-Dansk Ordbog er i stand til fuldt ud at tilfredsstille brugerkredsens behov med hensyn til en eller flere af ovenstående funktioner, så er den et kvalitetsprodukt. Hvis ikke, har den afgjorte konceptionelle mangler, som må afhjælpes i en kommende femte udgave. Lad os derfor kort set på, hvilke kategorier af leksikografiske angivelser hver af de nævnte funktioner kræver, og hvorvidt disse kategorier er inkluderet i Spansk-Dansk Ordbog.

\section{Reception af mundtlige og skriftlige spanske tekster}

De to funktioner, som man oftest opererer med i forbindelse med en bilingval ordbog fra fremmedsprog til modersmål, er reception og oversættelse. Spansk har den fordel frem for mange andre sprog, at det udtales, som det skrives. Og omvendt kan man stort set i alle tilfælde konstruere skrivemåden ud fra talesproget. Der findes kun enkelte generelle problemer (såsom stumt $h \operatorname{og} b=v$ ), som kan drille den ukyndige. Reception af talt og skrevet sprog kan derfor i denne henseende behandles under ét i en leksikografisk sammenhæng.

Hvad har en bruger behov for i forbindelse med reception? For det første skal vedkommende kunne finde det rigtige opslagsord. Det kræver, 
at usædvanlige fleksionsformer selekteres som selvstændige lemmata, hvorfra der kan henvises til grundformen. Det gælder ikke mindst, hvis brugergruppen indbefatter spanskstuderende på begynderniveau. SpanskDansk Ordbog anfører sådanne stærkt uregelmæssige former, men det sker på en så inkonsekvent måde, at det mest af alt minder om en ensalada rusa. F.eks. er både pongo, ponga og puse med. Det samme er tengo og tuve, hvorimod man leder forvæges efter tenga (som er en del hyppigere end ponga). Allerværst bliver det dog ved et ord som ser. Her finder man rimeligt nok præteritum-formerne fui og fue samt imperfektum konjunktiv-formen fuera, som ser har til fælles med verbet ir (at gå). Derimod virker det helt ulogisk, at man ikke kan finde præsens-formerne soy, eres, es, somos, sois og son, præsens konjunktiv-formen sea og imperfektum-formen era, som alle er stærkt uregelmæssige. Og det især set i lyset af, at tvillingeordet estar (der også betyder »at være«) er præsenteret under præsens-formerne estoy og está, præsens konjunktiv-formen esté og præteritum-formen estuve, som trods alt er mindre uventede end ser's aparte fleksionsmønster. Her er et oplagt opgave for en gennemrevidering inden femte udgave. Det er en fejl, som afgjort kan bebrejdes redaktøren og forfatteren. Men også forlaget må bære sin del af skylden, hvis det ikke i sine leksikografiske instrukser til forfatterne har opstillet klare regler for behandling af dette problem.

Det næste, som en bruger behøver i forbindelse med reception, er sikkerhed for, at vedkommende har fundet det rigtige opslagsord. Dette kræver - ud over at opslagsordet er stavet rigtigt - angivelser af ordklasse og køn, som de findes i Spansk-Dansk Ordbog. Men desuden fordrer det, at de ovennævnte stærkt uregelmæssige fleksionsformer anføres under den lemmatiserede form, hvor ordet behandles leksikografisk. Hvis brugerens udgangsord f.eks. er tenga, skal vedkommende være sikker på, at det er dette ord, som er beskrevet under den lemmatiserede form tener. Dette er ikke tilfældet i Spansk-Dansk Ordbog, og det er afgjort en mangel.

Det næste - og essentielle - brugerbehov ved reception er en redeg $\emptyset$ relse for opslagsordets semantik. Denne redegørelse kan enten ske ved hjælp af en eller flere danske ækvivalenter eller ved hjælp af en forklaring. Spansk-Dansk Ordbog anfører et stort antal ækvivalenter (ofte flere til hver betydning), hvorimod den kun benytter forklaring i meget få tilfælde som f.eks. albóndiga (lille krydret kød- el. fiskefrikadelle). Ydermere 
har brugeren behov for en forklaring eller oversættelse af typiske ordforbindelser, både gennemsigtige (kollokationer) og ikke mindst ugennemsigtige (idiomer). Også det kan man i rimeligt omfang finde i Spansk-Dansk Ordbog, som det fremgår af artiklen bota (se ovenfor). Endelig burde en receptionsordbog medtage de mest almindelige ordsprog, som benyttes hyppigt i daglig tale og skrift. Her yder SpanskDansk Ordbog dog ingen hjælp.

Alt i alt kan det dog konkluderes, at man - når man først har fundet det rigtige opslagsord - er temmeligt godt afhjulpet, hvis man ønsker at benytte Spansk-Dansk Ordbog til reception af mundtlige og skriftlige spanske tekster.

Der er dog et lille men. Hvis man som bruger samtidig med reception $\emptyset$ nsker at benytte opslaget som et led i en indlæringsproces, kan man nemt blive offer for den »blandede bilingvisme«, som Scerba (1986) kraftigt advarede mod. Dette spørgsmål vil blive behandlet nedenfor i afsnittet om tilegnelse af det spanske sprog.

På samme måde er Spansk-Dansk Ordbog ikke synderligt egnet til en mere dybtgående reception af kulturspecifikke spanske forhold. Det er naturligvis ikke forkert at oversætte bautizo, boda og Tribunal Suprema med dåb, bryllup og højesteret. Men det kan give brugeren en falsk tryghed, hvis vedkommende forledes til at tro, at disse fænomener indebærer de samme forhold og ritualer som i Danmark. Ordbøgers rolle er at yde bistand og give vished, ikke at skabe nye problemer. For at opfylde et brugerkrav af denne type er det derfor nødvendigt at inkludere en stor mængde kulturspecifik viden i ordbogen. En sådan ordbog findes så vidt vides endnu ikke til spansk, heller ikke som monolingval ordbog. Men her kunne den engelske leksikografiske tradition givetvis inspirere.

\section{Oversættelse af spanske tekster til dansk}

Oversættelse er par excellence den »klassiske« funktion i bilingvale ordbøger. Det var f.eks. denne funktion, som var omdrejningspunktet i den nu forældede »aktiv-passiv « teori, som blev udviklet af Kromann et al. (1984). For at gøre en ordbog velegnet til oversættelse kræves i første omgang, at brugeren kan finde de pågældende opslagsord. Her gør den samme problematik sig gældende som i forbindelse med første fase af en reception. Spansk-Dansk Ordbogs styrke og svaghed på dette felt er derfor allerede udpenslet i foregående kapitel. 
Centralt i en spansk-dansk oversættelsesordbog står behovet for et stort antal danske ækvivalenter til de spanske opslagsord og deres forskellige betydninger. Og i modsætning til en ordbog, som går fra modersmål til fremmedsprog, er der ikke behov for betydningsadskillende markeringer, idet brugeren i en bestemt kontekst formodes at kunne vælge den rigtige ækvivalent blandt flere ved hjælp af sin modersmålskompetence. Forklaringer og parafraseringer er derimod ikke specielt nyttige, da de ofte kræver en del omskrivning og kreativitet for at kunne indsættes i en konkret dansk kontekst. Spansk-Dansk Ordbog har - som nævnt ovenfor - en overvægt af ækvivalenter i forhold til forklaringer. Dermed er den på rette spor, idet den endvidere ofte indeholder flere ækvivalenter til de enkelte spanske opslagsord og deres forskellige betydninger. Men for virkelig at være en oversættelsesordbog burde den dog have medtaget flere synonymer til de danske ækvivalenter. En oversætter kan ofte ikke med det vons komme på alternative oversættelseskandidater, da vedkommendes kreative evner er sporet ind på andre problemstillinger i den intellektuelt set meget krævende oversættelsessituation. En ækvivalent- og synonymfattig ordbog kan derfor bidrage til en mindre varieret og mere stereotyp og falmet sproglig stil.

Ud over de egentlige ækvivalenter til opslagsordet har en oversætter brug for et stort antal oversættelsesforslag til ordforbindelser af både den ene og anden slags. Som vi har set ovenfor med bota i teksteksempel 1, er Spansk-Dansk Ordbog rimeligt udstyret på dette område. Men også her gælder det, at hvis ordbogen skulle yde en potentiel oversætter virkelig topservice, ville det fordre et langt større antal ordforbindelser, som ofte volder store problemer i forbindelse med oversættelse.

Den generelle konklusion må således være, at Spansk-Dansk Ordbog er med et godt stykke af vejen, men alligevel ikke fuldstændig egnet som oversættelsesordbog.

Men denne konklusion må relativeres i forhold til den konkrete brugergruppe og arten af de tekster, som skal oversættes. Det spørgsmål, som umiddelbart trænger sig på, er, i hvor høj grad der overhovedet finder oversættelse sted mellem spansk og dansk.

Litterær oversættelse af spanske tekster til dansk finder sted i et vist, men dog begrænset omfang. Men den vil næppe kunne udføres alene med anvendelse af Spansk-Dansk Ordbog. Ovenstående bemærkninger 
er fremfor alt relevante for denne type oversættelse, som kræver stor sproglig ynde og variation, hvor ordbogen klart har sine begrænsninger.

Oversættelse af spanske fagtekster finder sted i noget større omfang. Men naturligvis kan heller ikke denne type oversættelse foretages alene med brug af Spansk-Dansk Ordbog, som ikke selv giver sig ud for at være en fagordbog. Den vil allerhøjst kunne bruges som basis og supplement til en fagordbog ved oversættelse af de »almensproglige« ord og udtryk, som optræder i fagsproget, uden at deres betydning og almindelige brug er ændret. I den sammenhæng udgør den begrænsede sproglige og stilistiske variation i Spansk-Dansk Ordbog intet stort problem, men kan undertiden endda være en fordel.

Herudover finder oversættelse - på godt og ondt - sted i forbindelse med undervisning i spansk. Hvis det sker i forbindelse med uddannelse af oversættere, kan Spansk-Dansk Ordbog udmærket indgå i denne undervisning med de begrænsninger, som er nævnt ovenfor. Men en sådan undervisning udgør en forsvindende del af den spanskundervisning, som finder sted på landets uddannelsesinstitutioner og aftenskoler. I al anden sprogundervisning er - især skriftlige - oversættelser ofte af det onde, da de er med til at udvikle den »blandede bilingvisme«, som vil blive behandlet nedenfor. Spansk-Dansk Ordbog er på sin vis fremragende som hjælp til disse oversættelser, men spørgsmålet er altså, om den her ikke har samme funktion som rebet om den hængtes hals.

I alle andre situationer foretages der kun i begrænset omfang oversættelser mellem spansk og dansk. Men bevares: Spansk-Dansk Ordbog er uundværlig som hjælpemiddel til oversættelse af mosters opskrifter og lillesøsters kærestebreve efter ferieturen til Costa del Sol.

\section{Produktion af mundtlige og skriftlige spanske tekster}

Det var Mugdan (1992), der som den første systematisk argumenterede for, at bilingvale ordbøger fra fremmedsprog til modersmål med fordel kan benyttes til tekstproduktion på fremmedsproget, og hvilke krav en sådan funktion stiller til disse ordbøger. Selv om ideen allerede var sået af Scerba i 1940'erne, så repræsenterede den revolutionerende nytænkning inden for den leksikografiske tradition - om end knap så revolutionerende inden for den praktiske anvendelse af ordbøger, hvor mange brugere allerede havde fundet ud af at benytte bilingvale ordbøger 
til netop dette formål. Men fra teorien har ideen haft svært ved at trænge ind i den praktiske koncipering og udarbejdelse af nye bilingvale ordbøger. Leksikografisk praksis er om muligt endnu mere traditionsbundet end store dele af den teoretiske leksikografi.

For at kunne bruge en spansk-dansk ordbog som produktionsordbog kræves det, at brugeren ved, hvilket ord vedkommende skal slå op under. Det forudsætter, a) at man kender ordet i forvejen, b) at man har hørt eller set ordet i anden sammenhæng, eller c) at man er blevet henvist til det fra et indeks eller lignende.

Fordelen ved at bruge en spansk-dansk ordbog som produktionsordbog - frem for en dansk-spansk ordbog, som umiddelbart vil forekomme det fleste logisk - er, at brugeren på denne måde vender sig til at tage udgangspunkt i det spanske sprog og ikke først tænke og konstruere sætningerne på dansk. I praksis indebærer det et vist niveau på spansk. Begyndere vil normalt være henvist til en dansk-spansk ordbog, mens man - efterhånden som man bliver bedre til spansk - i stigende grad vil have fordel af at gribe direkte til en spansk eller spansk-dansk ordbog $\mathrm{i}$ forbindelse med tekstproduktion. Dog ville et ikke-leksikografisk danskspansk indeks til en spansk eller spansk-dansk ordbog også kunne hjælpe en begynder til allerede fra starten at vænne sig til at tage udgangspunkt i det spanske sprogs forunderlige verden. Men dels er en sådan ordbog endnu ikke tilgængelig på spansk, og dels kræver det nytænkning og indførelse af andre pædagogiske principper i sprogundervisningen.

Men kan Spansk-Dansk Ordbog anbefales som produktionsordbog for viderekomne eller avancerede danske brugere? Der stilles to slags hovedkrav til en fremmedsproglig produktionsordbog: Dels en redegørelse for fremmedsprogets semantik og dels en redegørelse for dets grammatik (morfologi og syntaks). Som vi har set ovenfor, er SpanskDansk Ordbog rimeligt med, hvad angår den semantiske beskrivelse (trods de allerede nævnte begrænsninger). Derimod er der ingen angivelser af de spanske ords fleksionsmorfologi. Og der er heller ikke til trods for et rimeligt stort antal ordforbindelser anført nogle eksplicitte generelle regler for deres syntaktiske egenskaber. Las os se på de to spanske verber rogar og solicitar:

rogar $v t .1$ bede $~$ a Dios; bede

(om, at), el joven les -ó que esperasen

den unge mand bad dem (om at vente).

$2 \mathrm{H}$ anmode. 


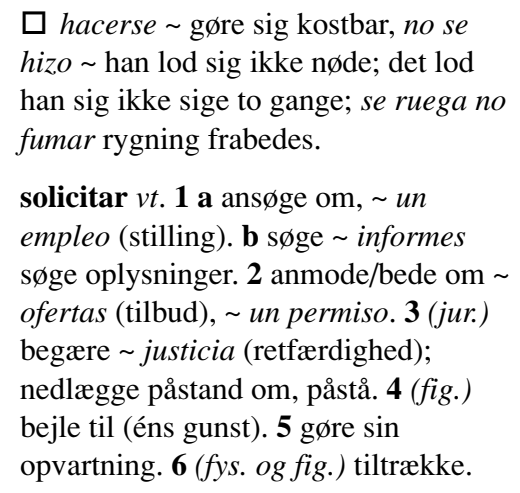

Eksempel 4: Artikler fra Spansk-Dansk Ordbog

Under rogar får man først at vide, at det drejer sig om et transitivt verbum. Men dette er en meget upræcis angivelse, da det kan dække over flere forskellige typer syntaktiske konstruktioner. Derudover bliver der ikke eksplicit angivet noget som helst. Men nærlæser man de konkrete ordforbindelser, fremgår det implicit, at rogar kan forbindes med såvel que-sætning som infinitiv. Og det må siges at være temmelig nyttige oplysninger ved sprogproduktion. Derimod får man ikke et kuk at vide om, at rogar også kan tage direkte objekt i form af et substantiv - rogó a los asistentes un poco de silencio (VOX) - og i den sammenhæng forbindes med et indirekte objekt. Under solicitar er det lige omvendt. Her får man ud over oplysningen om, at det er intransitivt, kun implicitte eksempler på, at det kan tage direkte objekt i form af et substantiv. Men man får ikke at vide, at det også kan forbindes med que-sætning og infinitiv, om end disse konstruktioner er knap så hyppige.

Konklusionen er derfor, at Spansk-Dansk Ordbog på grund af totalt manglende fleksionsmorfologiske og meget upræcise syntaktiske angivelser kun i ringe grad kan bruges ved sprogproduktion på spansk.

\section{Tilegnelse af det spanske sprog}

Ordbøger kan også konciperes til indlæring og tilegnelse af et fremmedsprog. Det er hovedtanken bag de såkaldte lørnerordbøger (diccionarios de aprendizaje). Der er skrevet side op og side ned om lørnerleksikografi. Hovedparten af denne litteratur er teoretisk meget svagt funderet og beskæftiger sig med konkrete og sprogspecifikke 
problemstillinger, der ikke har generel teoretisk relevans og interesse. Men den lille del af denne litteratur, som forsøger at stable en generel teori for lørnerleksikografi på benene, synes at pege i retning af, at lørnerordbøger er komplekse størrelser, som kræver et samspil mellem i det mindste tre forskellige typer funktioner: a) reception af fremmedsproget, b) produktion på fremmedsproget og c) tilegnelse af fremmedsprogets »system «, dvs. »ordforråd og grammatik «. De to første funktioner er rimeligt beskrevet i den leksikografiske litteratur, hvad man dog ikke kan sige om den tredje. Og med hensyn til samspillet - og sammenfletningen - af de tre funktioner, er dette stadig forholdsvis ukendt land. Og til syvende og sidst hænger de sammen med en bestemt fremmedsprogspædagogisk opfattelse. Det blev allerede klart i de overvejelser, som Scerba gjorde sig i 1940'erne, og som stadig ligger til grund for enhver seriøs diskussion om lørnerordbøger.

Scerba (1986) - som er en oversættelse af forfatterens oprindelige tekst fra 1941 - advarer kraftigt mod en såkaldt »blandet bilingvisme«, som nemt kan blive resultatet, når man tilegner sig et fremmedsprogs semantik gennem sit eget modersmål, dvs. gennem ækvivalenter, som ofte ikke er totalt dækkende for fremmedsprogets semantik. Scerba foreslog derfor, at man kun anfører ækvivalenter, når der er totalt betydningssammenfald mellem fremmedsprogets og modersmålets ord. I alle andre tilfælde anbefalede han en forklaring. Naturligvis må Scerba tages med et gran moderne salt, idet en række - kumulative - ækvivalenter til hver fremmedsproglig betydning kan indkredse fremmedsprogets semantik og dermed i høj grad råde bod på dette problem. I den forstand er Spansk-Dansk Ordbog i sit udgangspunkt ikke ringe stillet. Men alligevel kunne man have forventet flere forklaringer i ordbogen, end det er tilfældet. Det gælder selvsagt under kulturbestemte opslagsord som bautizo, boda og velar, som den katolske tradition i Spanien tilfører andre bibetydninger end på dansk. Men det gælder også ved andre, knap så kulturbestemte ord og udtryk. Lad os f.eks. tage artiklen trepar fra Spansk-Dansk Ordbog og sammenligne den med den tilsvarende artikel i en spansk lørnerordbog:

trepar vi. 1 klatre a un árbol (op i et træ); las plantas -an por la pared (klatrer op ad væggen).

2 blive forfremmet.

Eksempel 4: Artikel fra Spansk-Dansk Ordbog 
trepar Itrepárl 1 intr. Subir a un lugar
alto y difícil ayudándose de los pies y
de las manos: los niños treparon al árbol
más alto; treparon por la pared y
saltaron al otro lado; el gato trepó hasta
la copa del manzano. => encaramar. 2
Crecer ciertas plantas subiendo y
sujetándose a los troncos y ramas de los
árboles, a las varas y a otros objetos: la
yedra trepaba por la tapia; puso unas
cañas para que trepara la vid. 3 fam.
Conseguir un puesto importante o una
posición social alta usando todos los
medios posibles: ha amasado sufortuna
trepando y adulando a los demás.

Eksempel 5: Artikel fra VOX

Det danske ord klatre svarer ganske godt til første og anden betydning i den spanske artikel. I disse tilfælde vil denne ækvivalent være forsvarlig. Derimod er blive forfremmet både misvisende og betydningsfattig i forhold til den tredje spanske betydning. Her ville en dansk parafrasering eller forklaring have været på sin plads. Det kunne f.eks. være en mere eller mindre ordret oversættelse af den spanske forklaring: »Opnå en vigtig post eller høj position i samfundet ved brug af alle midler«.

Der kan anføres mange andre eksempler på dette problem, men det ville kræve en langt mere omfattende - og i $\varnothing v$ rigt meget interessant analyse og fremstilling. Men det korte af det lange er, at Spansk-Dansk Ordbog på dette område adskillige steder lægger op til den »blandede bilingvisme«, som burde høre fortiden til. Og når dertil lægges, at ordbogen overhovedet ikke kan anvendes til tekstproduktion på spansk, må den logiske konklusion være, at Spansk-Dansk Ordbog ikke egner sig som lørnerordbog og følgelig ikke kan anbefales som sådan.

\section{Konklusion}

Det har været en hel Vuelta a España at komme i mål. Gyldendals umeddelsomme forlagspolitik har skabt et sandt forhindringsl $\varnothing \mathbf{b}$ for den anmelder, som vil give et kvalificeret bud på kvaliteten af forlagets produkt. Og det samme gælder for den potentielle køber, som ønsker at finde ud af, om ordbogen lever op til vedkommendes behov. En sådan markedsføring kan kun et monopol eller kvasi-monopol tillade sig. 
Det er egentlig synd, for den overordnede konklusion er, at SpanskDansk Ordbog slet ikke er så ringe endda. Man skal blot vide, hvad den egner sig til. Det må således kraftigt frarådes at købe den med henblik på sprogproduktion og tilegnelse af det spanske sprog. Men hvis man hører til de få udvalgte, som har et reelt behov for at oversætte, så kan ordbogen anbefales - i det mindste som supplement til andre ordbøger. Og hvis man ønsker en ordbog som hjælp til at læse, lytte til og forstå spanske tekster, så er Spansk-Dansk Ordbog absolut ikke det værste, man forestille sig.

\section{Litteratur}

Kromann, Hans-Peder / Riiber, Theis / Rosbach, Poul (1984). Überlegungen zu Grundfragen der zweisprachigen Lexikographie. In Herbert Ernst Wiegand (Hrsg.): Studien zur neuhochdeutschen Lexikographie V. Hildesheim/New York: Olms, s. 159238. (=Germanistische Lingvistik 3-6/1984).

Mugdan, Joachim (1992). Zur Typologie zweisprachiger Wörterbücher. In Gregor Meder / Andreas Dörner (Hrsg.): Worte, Wörter, Wörterbücher: lexikographische Beiträge zum Essener Linguistischen Kolloquium. Tübingen: Niemeyer, s. 25-48.

Scerba, L.V. (1982). Versuch einer allgemeinen Theorie der Lexicographie. In Werner Wolski (Hrsg.): Aspekten der sowjetrussischen Lexicographie. Übersetzungen, Abstracts, bibliographische Angaben. Tübingen: Niemeyer, s. 17-62.

Tarp, Sven (1998). Leksikografien på egne ben. Fordelingsstrukturer og byggedele i et brugerorienteret perspektiv. In Hermes, Journal of Linguistics no. 21. Århus: Handelshøjskolen i Århus, s. 121-137.

Tarp, Sven (1995). Wörterbuchfunktionen: Utopische und realistische Vorschläge für die bilinguale Lexikographie. In H.E. Wiegand (Hrsg.): Studien zur zweisprachigen Lexikographie mit Deutsch II. Germanistische Linguistik 127-128. Hildesheim/New York: Olms, s. 17-51.

Vater, Pia / Winding, Ulla. Spansk-dansk Ordbog. 1. udgave. København: Gyldendal 1986.

Vater, Pia / Winding, Ulla. Spansk-dansk Ordbog. 2. udgave. København: Gyldendal 1988.

Vater, Pia. Spansk-Dansk Ordbog. 3. udgave. København: Gyldendal 1993.

Vater, Pia. Spansk-Dansk Ordbog. 4. udgave. København: Gyldendal 2000.

VOX. Diccionario para la ensenanza de la lengua española. Barcelona: Bibliograf 1995. 
